\title{
MISTIFICĂRI ȘI RECUPERĂRI BIOGRAFISTE: „CAZUL” LUCIAN BLAGA
}

\section{Ioana Pavel, Universitatea „Babeș-Bolyai”-Cluj-Napoca}

\begin{abstract}
This study is based on a research on literary criticism, with a focus on several aspects of Lucian Blaga's biography from an ideological perspective, aiming and examining its falsifications before 1989 and its true version after the socialist period. Due to most of the papers published by his daughter, Dorli Blaga (more specific, correspondence, diaries and official documents), we could claim that Blaga represents not only a literary case, but also a political one. To be more precise, the purpose of this article is to reveal some demystifications directly related to his biography, outlining three main periods in what concerns Blaga's reception: the '50s, the ' $60 \mathrm{~s}$ and the after '90s.
\end{abstract}

Keywords: biography, falsifications, demystifications, literary and political case, reception

Lucian Blaga e unul dintre acele nume ale literaturii române pentru care interesul nu se rezumă doar la opera literară sau filozofică, ci se extinde şi în privința aspectelor biografice care o pot lumina, măcar într-o perspectivă a aproximărilor date de modurile de receptare a activităţii de creaţie. Intenţia studiului de faţă este aceea de a contura direcţiile principale ale receptării în etape a operei (poetice, în special) în relație cu biografia, observând raportul dintre mistificările aspectelor „vulnerabile” ideologic înainte de 1989 şi restituirea, revalorificarea sau, pur şi simplu, corectarea lor odată cu anii ' 90 , când, pe lângă tentaţia revelării ,secretelor” autorului, apar textele memorialistice / cu valenţe autoficţionale (romanul Luntrea lui Caron, jurnalul Corneliei Brediceanu-Blaga, corespondenţa, documentele dosarului de urmărire şi mărturiile fiicei), dar şi studii atent documentate, care încearcă să restituie versiunea „obiectivată” a vieții sale.

\section{Lucian Blaga - un „caz” al literaturii române?}

Având în vedere profilul individual pe care îl deține interiorul canonului, Lucian Blaga rămâne ilustrativ pentre calitatea sa de dublu „caz”: întâi, e unul politic, cu dosar de urmărire informativă deschis de Securitate în 1955 (documentele sunt restituite şi comentate de Dorli Blaga şi de Ion Bălu ${ }^{1}$,

\footnotetext{
${ }^{1}$ Comentariile nu se rezumă la clarificarea evenimentelor ori la relaţionarea dintre relatarea lor și adevăratul sens, ci implică şi corectarea informaţiilor cuprinse în documente. Iată un exemplu redat de Ion Bălu: „«Ministerul Afacerilor de Interne. Director de cabinet. Lucian Blaga a fost în timpul dictaturii, ambasador la Lisabona numit de Mareşalul Antonescu la stăruinţele doamnei Goga. Actualmente stă deoparte.» Declaraţia nu e semnată, nici datată. Declaraţia e falsă, deoarece
}

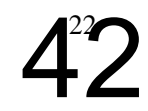


cel mai important biografist al autorului), scriitor interzis, cenzurat, scos din bibliografiile şcolare şi universitare; apoi, e şi un „caz” literar, pentru că, pe de o parte, anumite aspecte ale operei nu pot fi citite decât în prezenţa informaţiilor care ţin de cel politic (aşa se explică, de exemplu, faptul că proiectul filozofic al celor cinci trilogii a rămas neîncheiat sau că opera a fost receptată neuniform şi trunchiat), iar, pe de alta, e evident că se numără printre scriitori proteici ai literaturii române, atipic ca formaţie intelectuală şi ca „gust" literar, discutat obsesiv în condiţiile relaţiei dintre poezie şi sistemul filozofic pe care îl propune.

Motivele receptării deformate a operei lui Blaga înainte de 1989 ţin de contextul istoric şi de schimbările politice de pe plan naţional. În contextul instaurării regimului prosovietic în România, activitatea sa literară din perioada interbelică (neacceptată de noul sistem) e supusă criticii realismului socialist (Baghiu, 2013). Cea mai mare „vină” a filozofului de această dată apare în urma articolelor publicate în Gândirea despre problema etniei. Deşi, ulterior, Blaga îşi delimitează teritoriul conceptelor pe care le propune, restrângând concluziile pe o hartă mai strict delimitată, ,spre a le împiedica să se identifice cu doctrina fascismului" (Crohmălniceanu, 1963, 63), mişcările de dreapta nu au ezitat să îl revendice drept ideolog. În fapt, critica ideologică s-a îndreptat mai vehement împotriva filozofiei decât împotriva poeziei, iar acest lucru nu se datorează doar aşa-zisei orientări „de dreapta” revendicate ulterior, ci şi faptului că ideologii vremii fie nu îi înţeleg sistemul estetic şi filozofic pe care îl propune, fie îl intuiesc ca model al gândirii autonome, motiv suficient pentru declanșarea măsurilor împotriva activității sale literare. Mai mult decât atât, noul regim e profund deranjat de formaţia intelectuală germanofilă (afiliat, cu precădere, idealismului german), dar şi de prestigiul internaţional de care se bucura deja (Baghiu, 2013).

\section{Din... „tăcerile” criticii literare: anii '50}

Dacă debutul lui Blaga din 1919 cu Poemele luminii şi Pietre pentru templul meu a fost întâmpinat cu mult entuziasm (Sextil Puşcariu, Nicolae Iorga), analizele operei sale între 1948 şi 1961 sunt reduse la... tăcerea criticii literare. În Istoria critică..., Manolescu observă:

Între 1948 şi 1961, nu s-a publicat niciun rând despre poezia lui Blaga. Ultima referinţă este a lui G. Călinescu din Poezia realelor, prima, după 13 ani, tot a lui Călinescu din Contemporanul, dacă nu punem la socoteală protestul unui Nestor Ignat, scandalizat prin anii '50 de eventualitatea reluării „tradiţiei” decadente, ori necrologurile rostite de Ion Agârbiceanu şi de Aurel Rău la înmormântarea poetului. Critica poeziei se reia prin discriminarea ei de la filosofia

Blaga a fost ministru (şi nu ambasador) la Lisabona în 1938, numit de Regele Carol II.” (Bălu; Blaga, 1999, 8)

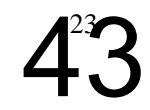


considerată de Călinescu însuşi, în acei ani, idealistă şi falsă. (Manolescu, 2008, 680-681)

Ideea e confirmată de teza de doctorat a Irinei Dincă (Lucian Blaga deschideri transdisciplinare. Stil, metaforă, receptare), care constată „hiatusul” receptării din anii realismului socialist, apelând la întregul corpus al textelor despre Blaga, adunate şi ordonate cronologic de Cornelia Blaga (Dincă, 2012, 322-324).

Făcând abstracţie de reacţiile în legătură cu traducerea lui $F_{a u s t}{ }^{2}$, istoria criticii româneşti înregistrează prima monografie a operei blagiene, după aceea a lui Vasile Băncilă din anii '30, ca fiind studiul lui Ovid S. Crohmălniceanu (1963). Explicaţia pentru această ,întârziere” apare şi pe fundalul politic al refuzului public al lui Blaga de a se număra printre membrii partidului (convins inițial de către asistentul său de la universitate, Zevedei Barbu, îşi anunţă ulterior demisia), astfel încât reacţia autorităţilor nu se limitează doar la interzicerea de a-şi tipări volumele, ci urmăreşte inclusiv scoaterea ei din reţeaua bibliotecilor, respectiv a bibliografiilor şcolare şi universitare şi, în consecinţă, impunerea modului de receptare, permisă fiind doar criticarea operei (Bălu, 1999, 122).

\section{Dumitru Micu}

Receptarea operei blagiene în anii '60: Ovid S. Crohmălniceanu şi

După atacul „revizionismului” din 1960, Crohmălniceanu face un gest surprinzător, dacă nu chiar paradoxal, recuperând unul dintre ,clasicii” literaturii interbelice prin monografia dedicată lui Blaga (apărută în 1963, pe fundalul politic al liberalizării). Studiul e reluat, cu mici diferenţe, în volumul al II-lea din Literatura română între cele două războaie mondiale. Criticul îl aminteşte însă şi în primul volum al aceluiaşi studiu, unde intenţionează, în capitolul dedicat gândirismului, să traseze ideologia mişcării şi să o situeze în raport cu alte aspecte de ordin social, cultural, istoric etc. ale epocii Blaga ocupă, în acest cadru, o poziţie-cheie, întrucât e văzut ca fiind unul dintre gânditorii orientării, cu toate că ideile filozofiei sale sunt adevărate „speculaţii” care rămân ,arbitrare” din cauza faptului că nu se bazează pe argumente ştiinţifice (Crohmălniceanu, 1972, 84).

\footnotetext{
${ }^{2}$ Referințele la traducerea lui Faust sunt, de fapt, singurele ocurențe pozitive ale prezenței lui Lucian Blaga pe harta literaturii din această perioadă. În raportul său despre traduceri prezentat la Congresul Scriitorilor din 1965, Alexandru Balaci semnalează: „Traducerile scriitorilor români din clasicii şi contemporanii literaturii apusene au atins, în acești ani, un înalt nivel de fidelitate creatoare, despre care grăiesc cu măiestrie şi prospeţime opere ca: La Fontaine în tălmăcirea lui T. Arghezi, Endre Ady, în româneşte de Jebeleanu, poemele lui Nerude în versiunea Mariei Banuş, ediţia nouă a Iliadei de G. Murnu, Faust de L. Blaga, Whitman în traducerea lui Mihnea Gheorghiu, Mickiewicz (Pan Tadeusz) de Miron Radu Paraschivescu, citând aici numai o seamă dintre ele." (Balaci, 1956, 170). Traseul receptării traducerii lui Faust în epocă e discutat pe larg de Ion Bălu (Bălu, 1999, 262 și urm.).
}

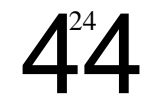


Crohmălniceanu atrage atenția asupra faptului că, deși asociat gândirismului, Blaga se pronunță vehement împotriva orientării ideologice (de dreapta) a mișcării, asumându-i exclusiv crezul estetic. Momentul politic de adoptare a limbajului regimului antonescian corespunde şi retragerii din scena gândiristă a mai multor nume, printre care se află şi Lucian Blaga (alături de Adrian Maniu, Ion Pillat, Gib Mihăescu, Cezar Petrescu) (Crohmălniceanu, 1972, 90-92). Cu toate aceste (re)orientări, nu se poate nega faptul că cel mai important merit al revistei a fost publicarea liricii universale expresioniste (de unde contactul şi, în continuare, influenţa artei expresioniste europene în spaţiul românesc) (Crohmălniceanu, 1972, 94), literatură pe care Blaga o apără în mod categoric.

În privinţa textelor critice despre poezie, probabil cea mai adecvată lectură e cea ,paralelă”, urmărind nuanţările şi diferenţele de expunere a ideilor, atât în raport cu biografia, cât şi cu opera. Ambele texte debutează cu problema dificultăţii de încadrare a lui Blaga într-o mişcare literară / într-un curent (Crohmălniceanu, 1963, 6 şi Crohmălniceanu, 1974, 192). Poetul e o figură atipică inclusiv în rândul gândiriştilor (Crohmălniceanu,1963, 14 şi Crohmălniceanu, 1974, 193), iar explicaţia cea mai plauzibilă pentru Crohmălniceanu în privinţa acestei individualizări ţine de formaţia sa intelectuală:

Într-o vreme când mai toţi literaţii noştri se aflau sub vraja lui Baudelaire, Rimbaud, Mallarmé, Valéry sau Jammes, idolii săi erau Goethe, Rilke, Ştefan George, Mombert şi Trakl. Pe tărâm speculativ, iarăşi, îl atrăgeau ideile unor Nietzsche şi Klages, Spengler şi Veihinger, Woringer şi Riegl, precoupările «Lebensphilosophiei» şi «Gestaltismului», «fenomenele originare» şi problemele de morfologia culturii. (Crohmălniceanu, 1974, 196-197; ideile se regăsesc şi în Crohmălniceanu, 1963, 14-15).

Demersurile comparatiste pot „testa” gradul de influență al numelor din listă, argumentând în ce măsură contribuie ele la formarea individualității creatoare. Dincolo de orientarea germanofilă, ușor de observat, e important de semnalat faptul că Blaga e „,conectat” la „spiritul veacului” său, refuzând efuziunile simboliste ori sentimentalismul romantic în favoarea misticismului expresionist, atras fiind de autorii ideilor de revoltă permanentă, de ciclicitate a civilizațiilor, de supraindividualitate a stilurilor ori de abstracție și intropatie, idei mai puțin „simpatizate" în efervescența culturală a interbelicului românesc.

Prezentarea sumară a elementelor biografice e, în mare măsură, aceeaşi, de la data şi locul naşterii, la şcolile prin care învaţă şi până la doctoratul susţinut la Viena, la traducerile din lirica universală şi Faust ori la cariera sa din străinătate (Crohmălniceanu, 1963, 16-21 şi Crohmălniceanu, 1974, 198-201). Una dintre diferențe apare în legătură cu prezentarea apariţiei

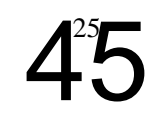


volumelor din 1919. Studiul din 1963 prezintă evenimentul ca pe o informație factuală (,În 1919 îi apar două volume: Poemele luminii şi Pietre pentru templul meu. Primul cuprinde versuri scrise în perioada studenţiei, celălalt, un şir de aforisme. Ambele volume sunt premiate de Academia Română." Crohmălniceanu, 1963, 19), în timp ce textul din 1974 aduce o modificare esenţială în raport cu şansa publicării, integrând inițiativa lui Blaga în acest demers: „Îndată după război, Blaga încredinţează tiparului rodul inspiraţiei lirice şi reflecţiilor sale din epoca studenţiei vieneze, sub forma a două volume subţiri. Unul, intitulat Poemele luminii, era o culegere de versuri, celălalt, Pietre pentru templul meu, cuprindea o serie de aforisme." (Crohmălniceanu, 1974, 199). Ceea ce e important de semnalat între aceste două variante ţine de episodul apariţiei Hronicului..., în ediţia din 1965, îngrijită de G. Ivaşcu, unde Blaga mărturiseşte faptul că iniţiativa publicării îi aparţine Corneliei (informație pe care Crohmălniceanu o avea la dispoziție, în munca sa de rescriere a variantei din 1963): ,în dorinţa de a pregăti editarea, a trimis, fără a-mi mai cere consimţământul [s.n.], poeziile mele profesorului Sextil Puşcariu de la Cernăuţi”" (Blaga, 2012, 231). Reacţia lui Puşcariu e extrem de favorabilă, el publică o recenzie a volumului Poemele luminii chiar înainte ca acesta să apară (Blaga, 2012, 242).

Din punctul de vedere al lui Crohmălniceanu, opera lui Blaga poate fi „salvată” prin lectura oblică a filozofiei sale reflectate în poezie. Comentând pe marginea sistemului filozofic (legat indivizibil de cel poetic), criticul observă ,pronunţate înclinaţii teiste, chiar mistice, dar nu are nimic comun cu credinţa creştină” (Crohmălniceanu, 1963, 8). Cu alte cuvinte, nu e poet religios / ortodox şi, prin urmare, poate fi recuperat pe harta literaturii române interbelice. $\mathrm{Cu}$ toate împotrivirile sale faţă de sămănătorismul acceptat de Nichifor Crainic, concepţia blagiană „suferă” din cauza unei viziuni extrem de conservatoare asupra satului românesc, manifestând „o neascunsă repulsie pentru orice transformare care i-ar putea altera acestuia sufletul primitiv" (Crohmălniceanu, 1963, 11). Aderența poetului la „opera constructivă a socialismului" (Crohmălniceanu, 1963, 21) e explicabilă, din nou, prin prisma formaţiei sale intelectuale în şcoala filozofică germană:

Tânărul care se întorcea în 1920 de la Viena se formase la şcoala spiritualismului şi iraţionalismului german din epoca imperialismului. Această orientare filozofică se făcuse simţită încă de la sfârşitul veacului al XIX-lea şi era determinată, în ultimă instanţă, de îngrijorarea pe care o inspira claselor stăpânitoare socialismul. Nevoia lor de a i se împotrivi cu orice mijloace începe să se reflecte destul de viu şi pe tărâm ideologic. (Crohmălniceanu, 1963, 25)

Pentru Crohmălniceanu, recuperarea lui Blaga se poate face prin apelul la construcţia mitică a satului (element care ține, în definitiv, de construcția 
identitară românească), idee obsesivă (uneori frustrantă chiar) pe parcursul întregii monografii:

satul îşi pierde complet orice realitate istorico-socială şi devine o pură construcție metafizică. Blaga concepe un soi de univers rural atemporal, imobil şi etern, un lăcaş simbolic imaginar, al sufletului copilăresc primar. Această reprezentare traduce, pe de o parte, neîncrederea în posibilitatea lumii burgheze de a mai menţine ordinea existentă, sentimentul că din chiar elementele societăţii capitaliste (marea producţie industrială, progresul tehnico-ştiinţific, maşinismul) se nasc inevitabil forţele care ameninţă să distrugă vechile aşezări, pe de altă parte, teama de zguduiri revoluţionare, refugiul într-o zonă închipuită ca refractară total răsturnării aşezărilor tradiţionale (clasele stăpânitoare de la noi s-au hrănit multă vreme cu iluzia neaderenţei structurale a țăranului român la orice formă de colectivism. (Crohmălniceanu, 1963, 31)

$\mathrm{Cu}$ alte cuvinte, viziunea mitic-arhaizantă a lui Blaga în raport cu satul e expresia „metaforică” a două aspecte favorabile din punct de vedere ideologic sistemului politic: e vorba, în primul rând, de posibilităţile capitaliste care pot distruge valoarea arhetipală a satului (ceea ce se poate citi şi drept o condamnare implicită a capitalismului); în al doilea rând, criticul vede în apărarea imaginii mitice concretizarea dorinţei de echilibru şi a temerii în faţa schimbărilor pe care le poate aduce fervoarea unei revoluţii care să aducă o schimbare radicală (idei acceptate de sistemul ideologic din interiorul căruia le discută). Totuşi, această gândire e amendată din mai multe motive: nu e ştiinţifică (Blaga nu îşi expune ideile suficient de „ştiinţific”, nu cercetează obiceiuri şi tradiţii cu ajutorul instrumentelor etnografiei şi ale sociologiei Crohmălniceanu, 1963, 56), iar iraţionalitatea care o caracterizează e ameninţată de construcţii ,nebuloase”, minate de contradicţii interioare ale sistemului de gândire (Crohmălniceanu, 1963, 60). În fapt, condamnarea iraţionalismului burghez e una dintre constantele criticii realist-socialiste, motiv de la care derivă şi atitudinea destul de acuzatoare a criticului, valabilă pentru întregul studiu şi menţinută, fără a atinge însă aceeaşi vehemenţă, în Literatura română dintre cele două războaie mondiale.

Monografia lui Crohmălniceanu evidenţiază punctele de forţă care coagulează volumele poetice: tentaţia misterului şi lumina ca forţă demiurgică în Poemele luminii (Crohmălniceanu, 1963, 68-70), panteismul şi consubstanţialitatea dintre eu şi natură în Paşii profetului (Crohmălniceanu, 1963, 79), ,îmblânzirea” expresionismului (în sensul de adaptare originală) în Laudă somnului, În marea trecere, La cumpăna apelor (Crohmălniceanu, 1963, 91). Teama în faţa schimbării şi căutarea echilibrului pe care lumea capitalistă e incapabilă să i-l ofere se transpun, în viziunea criticului, din filozofie şi în opera poetică, fapt evident prin abundenţa viziunilor

$$
47
$$


apocaliptice, contrabalansate într-o anumită măsură de poeziile de dragoste din ediţia din 1962, îngrijită de G. Ivaşcu. Concluzia lui Crohmălniceanu e formulată cu o anumită prudenţă, care îi permite să recupereze doar parţial opera lui Blaga: „Produs al unei rare sensibilităţi şi al unei imaginaţii prodigioase, altoite însă pe o gândire înfeundată spiritualismului şi iraţionalismului, opera lui Blaga nu se salvează în întregime din ruinele lumii de ieri." (Crohmălniceanu, 1963, 176). Modificările din Literatura română intre cele două războaie mondiale care apar la nivelul interpretării includ semnalarea resurselor folclorice ale poeziei blagiene (elemente absente în monografia din 1963): „Fiindcă utilizează copios un material folcloric, elemente ale eresurilor, credinţelor obscure şi practicilor magice [...] dă o stranie impresie de obiectivitate." (Crohmălniceanu, 1974, 240).

Aparținând tot anilor '60, monografia lui Dumitru Micu (1967) propune un alt tip de lectură a liricii blagiene, anticipând câteva dintre premisele criticii psihanalitice. Studiul oferă, la o lectură atentă şi „deconstructivă”, semnele raportării poeziei la biografie, prin debutul în care aşază muţenia copilăriei printre sursele de inspiraţie poetică, dar şi magicmetafizică:

Până la vârsta de patru ani, Lucian Blaga a fost, nu doar metaforic, „mut ca o lebădă”. De unde vedea, din ce obscure chemări regresive, această paralizantă teamă de cuvânt? $\mathrm{Nu}$ cumva, metafizicianul care avea să acorde, în meditaţiile lui, atâta însemnătate magiei, acţiona din negurile inconştientului, neidentificat şi nici măcar bănuit, asupra minţii firave a copilului? (Micu, 1967, 5)

Pornind de la metaforele propuse de Blaga, Dumitru Micu asumă în mod explicit acea distanţare de obiect care îi permite să transforme actul critic întrunul creator de idei, fixând, în acest fel, propria raportare la textul literar, precum şi ineditul interpretării: „Intocmai ca poetul, criticul «sporeşte a lumii taină». Când este autentic, actul critic e creator. Aidoma poetului, criticul îşi creează obiectul şi se autocreează în el.” (Micu, 1967, 9).

În privinţa hermeneuticii, criticul nu îşi reprimă (recunoscând acest lucru) ,avântul interpretativ" în faţa coincidenţelor pe care le observă între biografic şi literar (Micu, 1967, 10), ceea ce îi permite să citească, în volumul Poemele luminii, o carte a experienţelor sufleteşti, cu valoare apropiată de aceea a unui document autobiografic (Micu, 1967, 12), dezicându-se totuși, în mod paradoxal, de ,vulgara «explicare» biografică, opera de artă neavând nevoie de de aşa ceva, întrucât ea transcende până la anulare biograficul" (Micu, 1967, 13). Dacă lumina e simbolul coagulant al volumului de debut (Micu, 1967, 14), „pannaturismul” care sacralizează organicul (dar care va fi depăşit prin instanţierea imaginii hristice) din Paşii profetului e văzută ca anticipare a figurii lui Zamolxe (Micu, 1967, 18-20), în timp ce „ereziile”

\section{8}


poetice (motive religioase resemantizate) sunt reprezentări ale ideilor filozofice (Micu, 1967, 35).

Consideraţiile lui Crohmălniceanu despre atitudinea blagiană faţă de oraş, civilizaţie, tehnică etc. sunt răsturnate în lectura lui Micu: „Nu-i adevărat că scriitorul neagă civilizaţia, oraşul ca formaţiune concretă, idealizând satul, primitivitatea în înţeles istoric. Lucian Blaga este mai curând (nu fără confuzii, contradicţii şi inconsecvenţe) un apologet al civilizaţiei şi al tehnicii” (Micu, 1967, 40). Reversul medaliei e dat de sensul exagerării creaţiei umane în detrimentul naturii şi al spiritului; în acest punct, civilizaţia îşi întoarce asupra sieşi propriile arme, autosuprimându-se, de unde lirismul „sfâşierii” din volumele În marea trecere, Lauda somnului şi La cumpăna apelor (Micu, 1967, 41).

Studiul lui Micu e, prin excelenţă, o lectură tematică (urmărind, spre exemplu, recurenţa motivului luminii, imaginea muntelui ca ax ordonator al lumii, tema apocaliptică şi a „tristeţii metafizice”, dorul de ţară ca expresie a rupturii de spaţiul originar şi ordonator al fiinţei) care confirmă premisa anunţată în debutul volumului: criticul literar are posibilitatea de a opera cu acele decupaje care îi oferă posibilitatea de a-l recupera strict estetic pe poet, fără a-i „leza” imaginea prin argumente evidente de ordin ideologic.

\section{După anii '90. Biografism şi psihanaliză}

Începând din anii '90, critica literară nu mai are nevoie de strategii oblice pentru a recupera scriitorii „uitaţi” sau „epuraţi” ai literaturii române, având acces la documente de arhivă care permit restituirile strict biografice şi urmând ca, pe baza lor, studiile să corecteze diversele aspecte rămase în umbră sau, pur şi simplu, să îşi construiască întreg demersul hermeneutic prin apelul la versiunea „obiectivată” a biografiei. În acest sens, (re)editările Hronicului... şi ale romanului Luntrea lui Caron, ale memoriilor sau ale interviurilor despre Blaga (Dorli Blaga, Corneliu Blaga, Ioan Oprişan, Radu Cărpinişianu), analizele documentare (Ion Bălu, Mihaela Bacali) deschid o nouă etapă de reconstrucţie nu doar a biografiei, ci şi a operei care poate fi reanalizată inclusiv din punct de vedere valoric. În termenii lui Blaga însuşi (refuzând pactul ficțiunii din Luntrea lui Caron), tăcerile sau răstălmăcirile sunt conectate strict la un nume care face trimitere, într-adevăr, la o operă, la idei, la valori, însă acestea din urmă rămân inaccesibile publicului: „«Celebritatea» mea a pătruns, dacă nu până la talpa ţării, totuşi, într-un fel, până la bruma de intelectualitate de la sate. Celebritatea mea este însă pur nominală. Nu faptele, nu opera îmi sunt cunoscute, ci numele.” (Blaga, 2013, 275). Pe acest fond apar şi lecturile „romanţate” ale „secretelor” lui Blaga, în legătură cu muzele poetului (implicit, cu restituirile etapelor poeziei sale de dragoste sau) şi lectura mai degrabă literală a romanului (în această direcţie se înscriu nume precum Zenovie Cârlugea sau Ovidiu Pecican).

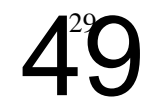


În fapt, direcțiile esențiale ale receptării operei și chiar a vieții lui Lucian Blaga de după anii ' 90 se pot rezuma la cea documentaristă (în continuarea căreia vine și tendința ,publicitară”, amintită deja) și cea psihanalitică, cu o puternică bază biografică.

În ordinea demistificărilor de ordin ideologic ale biografiei poetului, cea mai importantă dintre ele e, fără îndoială, restituirea documentaristă. Teritoriul e larg discutat, amintesc doar un episod reconstruit de Ion Bălu, care lezează imaginea unui Blaga „nealterat” de presiunile regimului socialist. E vorba despre articolul Probleme și perspective literare, apărut în 1960 în Contemporanul și, ulterior, în Scânteia, la îndemnul lui G. Ivaşcu (care se folosește de pretextul intrării în anonimat pentru a-l convinge să scrie), imediat după lucrările Comitetului de conducere a Uniunii Scriitorilor, întrunit pentru a discuta situația literaturii contemporane. Reacția lui Blaga corespunde întocmai sugestiilor lui Ivașcu:

„,...prin orientările ei”, literatura „trebuie să fie legată de viața poporului şi de solul Patriei”; amintea [Lucian Blaga - n.n.], în continuare, realizările evidente, petrecute ,,în toate sectoarele activității” și, pe aproximativ o treime din context, rostea ,un cuvânt mai apăsat" despre eficacitatea educativă, exercitată asupra „conștiinței literare a noilor generații de scriitori” de „o mirabilă” literatură universală, ,mutată în casa noastră”, prin traducerile sistematice din ultimii ani, datorate ,impetuoaselor inițiative culturale ale regimului de democrație populară din Republica noastră..." (Bălu, 1999, 361)

Un astfel de gest va fi imediat receptat de către intelectualitatea românească în termenii unei capitulări în faţa regimului politic, în timp ce istoriile literare recente ocolesc acest episod care, în pofida dezbaterilor estetice postnouăzeciste, poate afecta portretul (idealizat) cu care Blaga este aşezat pe harta criticii literare.

Dincolo de toate aceste încercări de restituire documentară sau „publicitară”, probabil cea mai fascinantă dintre lecturile biografiste este încercarea de ,psihanalizare” a operei blagiene, aşa cum se întâmplă în cazul studiului semnat Corin Braga. Premisa unei astfel de lecturi este aceea că sistemul pe care îl gândeşte Blaga (poezie, teatru şi filozofie) e un tot unitar, analizabil printr-un set de instrumente extrinseci lui, care să urmărească modul de configurare a imaginarului din punct de vedere fiziologic şi genetic; în caz contrar, sistemul şi raportul semnificaţiilor nu pot fi explicate în logica genezei şi a procesualităţii lor, ci e o inventariere de ordin anatomic, descriptiv (Braga, 2013, 52). Preluând conceptul Ioanei Em. Petrescu de „model cosmologic adoptiv", Corin Braga identifică în creaţia blagiană o succesiune de astfel de modele, care corespunde unei periodizări interne, nicidecum istorice şi biografice. Interesat doar de primele metamorfoze ale viziunii cosmologice,

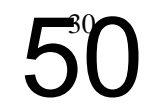


autorul se opreşte la ,„̧ărmul autobiografic" (formularea îi aparţine lui Bazil Gruia) al anului 1919 (Braga, 2013,63). Premisa cea mai importantă pe care se sprijină întreagul demers hermeneutic este „,complexul surorii moarte” (Braga, 2013, 7) sau al copilului „,nedorit” (Braga, 2013, 77). Acest complex al substituţiei va genera un adevărat mit al tăcerii, redat autobiografic în Hronic, dar şi în poezie (Autoportret) (Braga, 2013, 69-73). Logica ordonatoare a volumului e, de fapt, teza lui Freud despre analiza psihanalitică a biografiei, analiză care oferă semnificaţii amintirilor din copilărie (idee invocată de autor - Braga, 2013, 74). Tot în cheie psihanalitică (văzute drept căutări ale identităţii) sunt explicate şi scenariile erotice:

Cornelia Blaga pare să fi intuit că escapadele erotice ale soţului ei nu sunt simple infidelităţi, ci o încercare de regăsire a echilibrului interior, de unde atitudinea ei înţelegător-maternă. Blaga însuşi nu conştientizează resorturile comportamentului său şi al Corneliei, explicându-1 naiv grandilocvent, mitizant, de la nivelul eului narcisic, ca pe o coparticipare a soţiei sale la «demonia insondabilă a creaţiei» ce îl stăpâneşte. Dar, inconştient, el face conexiunea revelatorie între stările de cădere psihică şi scufundare în tăcerea infantilă şi reconfortul adus de afirmările erotice, ce avea loc cu aprobarea tacită a Corneliei. (Braga, 2013, 106)

Nici măcar opţiunile pentru arta expresionistă nu ţin de o construcţie raţională, ele sunt tot o expresie a unor stări inconştiente:

Formaţia vieneză a lui Blaga nu este doar o chestiune de accident biografic, ci una de afinitate electivă. [...] Nu temele şi nu tehnica «noului stil» îl captivează în primul rând, ci pur şi simplu ideea unei arte deschise spre abisalitate, capabilă să surprindă resorturile inconştiente şi cosmice ale creatorului. (Braga, 2013, 115)

$\mathrm{O}$ astfel de lectură (în cheie psihanalitică) nu e neapărat demistificatoare în intenții, însă vine pe fondul accesului criticii literare şi la instrumente care țin mai degrabă de inconștient, transcendent, adică de discipline tangențiale studiului literar și e posibilă în condițiile democratizării metodelor prin care literatura i se supune.

\section{În loc de concluzii}

Așadar, receptarea operei lui Lucian Blaga are loc în mai multe etape şi se desfăşoară pe niveluri eterogene, marcate şi de implicaţii ideologice. Dacă până în anii ' 60 , receptarea operei era fixată mai ales asupra filozofiei şi doar tangenţial asupra poeziei (prin critica de întâmpinare) ori e, pur şi simplu, absentă (anii '50), odată cu perioada liberalizării apar şi încercările de restituire a activităţii literare, întotdeauna relevate clişeic prin interdependenţa dintre sistemul filozofic şi creaţia poetică ori dramatică. Mistificările biografiei lui Blaga, fie că implică deturnări intenţionate ale adevărului, fie că trec sub tăcere anumite aspecte, sunt corectate de intervenţiile biografiştilor de după

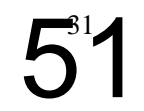


1990, ceea ce permite istoriei literare să reconsidere contextual încercările de sistematizare a operei lui Lucian Blaga și să amendeze lecturile deformate din motive de ordin ideologic.

\section{Bibliografie}

Baghiu, Ştefan, „Recuperarea operei lui Lucian Blaga în anii şaizeci. O evaluare a absenţei şi a condiţiilor recuperării”, în Cultura, nr. 446 din 14 nov. 2013, text disponibil pe http://revistacultura.ro/nou/2013/11/recuperarea-operei-lui-lucianblaga-in-anii-saizeci-o-evaluare-a-absentei-si-a-conditiilor-recuperarii/ [accesat în 23.10.2018].

Balaci, Alexandru, Traducerile literare, în ***, Lucrările Primului Congres al Scriitorilor din Republica Populară Română, 18-23 iunie 1956, Bucureşti, Editura de Stat pentru Literatură şi Artă, 1956.

Bălu, Ion, Viaţa lui Lucian Blaga, vol. al IV-lea, Bucureşti, Editura Libra, 1999

Bălu, Ion; Blaga, Dorli, Blaga supravegheat de Securitate, Cluj-Napoca, Editura Biblioteca Apostrof, 1999.

Blaga, Lucian, Hronicul şi cântecul vârstelor, ediţie îngrijită de Dorli Blaga, Bucureşti, Editura Humanitas, 2012.

Blaga, Lucian, Luntrea lui Caron, ediţia a IV-a, Bucureşti, Editura Humanitas, 2013.

Braga, Corin, Lucian Blaga. Geneza lumilor imaginare, ediţia a II-a, revizuită, studiu introductiv de Călin Teutişan, Bucureşti, Editura Tracus Arte, 2013.

Crohmălniceanu, Ovid S., Lucian Blaga, s. 1., Editura pentru Literatură, 1963.

Crohmălniceanu, Ovid S., Literatura română intre cele două războaie mondiale, vol. I, Bucureşti, Editura Minerva, 1972.

Crohmălniceanu, Ovid S., Literatura română între cele două războaie mondiale, vol. II, Bucureşti, Editura Minerva, 1974.

Dincă, Irina, Lucian Blaga - deschideri transdisciplinare. Stil, metaforă, receptare, teză de doctorat suş̧inută la Timişoara, 2012, disponibilă pe https://ciret-transdisciplinarity.org/biblio/biblio_pdf/irina_dinca.pdf [accesat în 25.10.2018].

Manolescu, Nicolae, Istoria critică a literaturii române. 5 secole de literatură, Pitești, Editura Paralela 45, 2008.

Micu, Dumitru, Lirica lui Lucian Blaga, Bucureşti, Editura pentru Literatură, 1967. 